\title{
Laser and Gas Metal Arc Based Dissimilar Joining of Automotive Aluminium Alloys and Steel Sheets - A Review
}

\author{
Atanu Das*, and Hee-Seon Bang*,† \\ *Welding and Joining Science Engineering, Chosun University, Gwangju, 61452, Korea \\ †Corresponding author : banghs@chosun.ac.kr \\ (Received September 18, 2018 ; Revised October 5, 2018 ; Accepted October 15, 2018)
}

\begin{abstract}
Multi-material joining of aluminium to steel is mainly restricted due to their different thermo-physical properties, melting temperatures, low solubility and in particular, formation of brittle intermetallic phase layer at the joint interface. Various joining processes have been attempted to join aluminium and steel sheets with an aim to reduce the growth of phase layer by precise control of heat input. However, laser beam and arc based joining processes are popular among other joining processes due to their strict control of heat input with regulative metal transfer and flexibility to join intricate shapes. A critical survey in joining aluminium to steel sheets by laser beam and arc based joining processes are presented in the present work. The influence of various joining parameters such as heat input, filler wire types on the growth of intermetallic phase layer thickness and corresponding joint strength are analysed and reported subsequently.
\end{abstract}

Key Words : Laser beam welding, Gas metal arc welding, Aluminum alloy, Galvanized steel

\section{Introduction}

Joining of multi-material combinations such as aluminium to steel has gained significant attention in the automotive industry as a recourse to enhance the strengthto-weight ratio of the vehicle structures ${ }^{1-5)}$. However, aluminium to steel joining is remain challenging due to their diverse thermo-physical properties, varying melting temperatures, poor solubility of aluminium in iron and in particular, formation of intermetallic phase layer with several Fe-Al brittle intermetallic compounds $(\mathrm{IMC})^{6)}$. Although presence of intermetallic phase layer is needed for the joint to form, however formation of thicker phase layer leads to embattlement of the joint ${ }^{5-7)}$. Experimental studies indicate stringent control of the heat input is required to reduce the extent of formation of phase layer during joining of aluminium alloys and galvanized steel sheets ${ }^{7)}$.

Various processes such as resistance spot welding $(\mathrm{RSW})^{8)}$, friction stir welding $(\mathrm{FSW})^{9)}$, laser beam ${ }^{10,11)}$ and $\operatorname{arc}^{6,7,12-15)}$ based joining techniques are attempted to join aluminium and steel with an aim to keep the heat input significantly low. Joining of complex contours us- ing FSW remained a problem while severe electrode wear due to chemical reaction between copper electrode and aluminium alloys inhibited use of RSW process in joining of aluminium alloys as well as of aluminium and steel ${ }^{9,16)}$. The use of laser and advanced pulsed current arc based joining processes is increasing in recent times due to their superior control over heat input with metal transfer rate, and flexibility to join out-of-position geometries $^{5-7,10,11)}$.

\section{Motivation}

Laser beam and pulsed current gas metal arc (GMA) based techniques could join thin metallic sheets of dissimilar materials at a very low power with moderate to reasonable high speed. The recently reported studies on application of laser beam and GMA based processes for joining of aluminium to steel sheets involved primarily the assessment of growth of intermetallic phase layer thickness with nature of IMCs at the joint interface and the corresponding joint strengths ${ }^{6,7,10,11)}$. Laser beam and GMA based processes commonly employed pure $\mathrm{Al}, \mathrm{Al}-\mathrm{Si}, \mathrm{Al}-\mathrm{Mg}$ filler wires as well as without filler wire in joining aluminium to steel sheets ${ }^{5-7,10-14)}$. Several 
authors found phase layer thickness in the range of 0.9 $\sim 30 \mu \mathrm{m}$ with corresponding joint strength around $80 \sim$ $201 \mathrm{MPa}$ using pure Al, Al-Si, Al-Mg filler wires ${ }^{7,10-12,14,15)}$. In another case, a heat input of $200 \mathrm{~J} \mathrm{~mm}^{-1}$ generated the phase layer thickness in the range of $3 \sim 5 \mu \mathrm{m}$ with maximum joint strength around $200 \mathrm{MPa}^{6}$. Most of the available studies reported usage of different types of filler wires with widely varying range of the heat input and phase layer thickness to obtain a sound and defect-free joint. In the present study, the current applications of laser beam and GMA based joining processes to make a suitable joint between aluminium alloys and different types of steel sheets are presented. The influence of joining parameters such as heat input, filler wire types and varieties of steel surface coating on growth of phase layer at the joint interface and corresponding joint strength are illustrated further in details.

\section{Laser Beam Based Joining}

Mathieu et al. ${ }^{17)}$ used typical heat input range of 50 $60 \mathrm{~J} \mathrm{~mm}^{-1}$ in laser beam joining of aluminium alloy to hot-dip galvanized (GI) steel sheets with Zn-15\%Al filler wire. The authors reported the formation of phase layer thickness around $5 \mu \mathrm{m}$ with joint strength of $190 \sim$ $230 \mathrm{~N} \mathrm{~mm}^{-1}$. A nearly similar filler wire composition was used by Dharmendra et al. ${ }^{18)}$ to join $1.2 \mathrm{~mm}$ thick AA6016 alloy to $0.77 \mathrm{~mm}$ thick GI steel sheets following heat input range of $30 \sim 180 \mathrm{~J} \mathrm{~mm}^{-1}$. Fig. 1 shows that authors achieve maximum joint strength around $200 \mathrm{MPa}$ for a heat input range of $60 \sim 110 \mathrm{~J} \mathrm{~mm}^{-1}$ by containing the phase layer thickness within $8 \sim 12 \mu^{18)}$. While, Shabadi et al. ${ }^{19)}$ used a heat input of $45 \mathrm{~J} \mathrm{~mm}^{-1}$ to join $1.2 \mathrm{~mm}$ thick AA6016 alloy and $0.7 \mathrm{~mm}$ thick

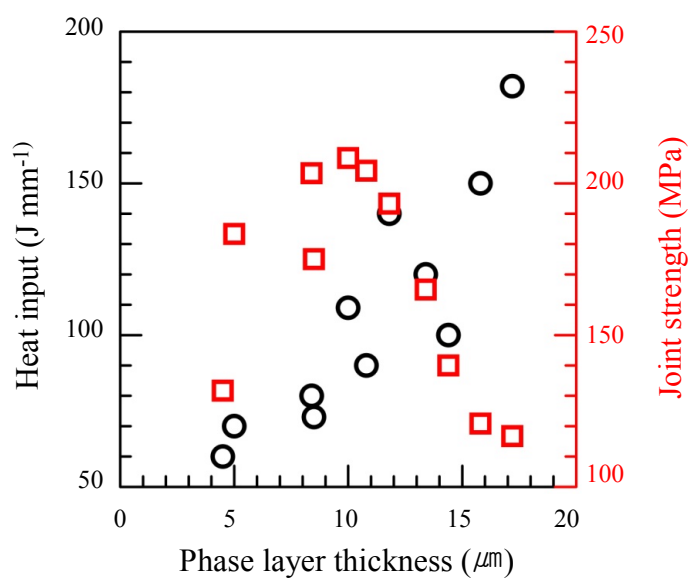

Fig. 1 Variation of heat input, joint strength and phase layer thickness in laser beam joining of aluminium alloy and steel sheets ${ }^{18)}$. Heat input and joint strength are marked by circle and square, respectively
GI steel sheets by laser beam based process using $\mathrm{Zn}-30 \% \mathrm{Al}$ filler wire. The phase layer thickness was found to be within $10 \mu \mathrm{m}$ with maximum joint strength of $190 \mathrm{MPa}^{19)}$.

Other authors used Si-based filler wire to join aluminium and steel sheets using laser beam due to their wider availability and ease of use. Sierra et al. ${ }^{10)}$ joined 1 mm thick AA6016 alloy to $1.2 \mathrm{~mm}$ thick GI steel sheet using a laser beam with AA4047 (Al-12\%Si) filler wire considering a heat input range of $120 \sim 150 \mathrm{~J} \mathrm{~mm}^{-1}$. The authors found phase layer thickness around $2 \mu \mathrm{m}$ and the maximum joint strength was $190 \mathrm{MPa}^{10)}$. While, Zhang et al. $^{20)}$ reported phase layer thickness in the range of $1.5 \sim 13 \mu \mathrm{m}$ with the maximum joint strength of $162 \mathrm{MPa}$ in joining of $1.15 \mathrm{~mm}$ thick AA6016 alloy and $1.2 \mathrm{~mm}$ thick GI sheets by AA4043 (Al-5\%Si) filler wire using heat input range of $138 \sim 156 \mathrm{~J} \mathrm{~mm}^{-1}$. A similar filler wire composition was used by Qin et al. ${ }^{21,22)}$ to join $1 \mathrm{~mm}$ thick AA6013 alloy and $2 \mathrm{~mm}$ thick GI steel sheets using a laser-GMA hybrid process. The phase layer thickness was restricted within $2 \sim 4 \mu \mathrm{m}$ and maximum joint strength was found to be around $247 \mathrm{MPa}^{21)}$.

Saida et al. ${ }^{23)}$ used the tandem laser beam process for joining of $1.2 \mathrm{~mm}$ thick AA6022 alloy and $0.8 \mathrm{~mm}$ thick GI and galvannealed (GA) steel sheets with AA4047 filler wire. The authors found maximum joint strength of $180 \mathrm{~N} \mathrm{~mm}^{-1}$ with phase layer thickness around $2 \sim 3 \mu \mathrm{m}$. Yang et al. ${ }^{24)}$ used heat input of around $70 \sim 168 \mathrm{~J} \mathrm{~mm}^{-1}$ to join $2 \mathrm{~mm}$ thick AA5754 alloy and $1 \mathrm{~mm}$ thick galvanized DP980 steel sheets by diode laser beam using AA4047 filler wire. Fig. 2 shows variation of joint strength as a function of heat input. The authors reported poor joint strength of $118 \mathrm{~N} \mathrm{~mm}^{-1}$ at a low heat input of $70 \mathrm{~J} \mathrm{~mm}^{-1}$, which was attributed to inadequate wetting of filler deposit on steel surface. At a medium heat input of $120 \mathrm{~J} \mathrm{~mm}^{-1}$, the joint strength was

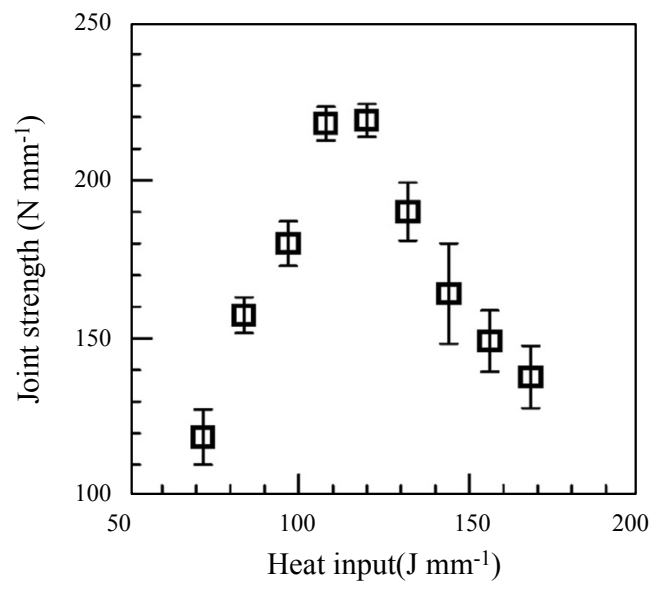

Fig. 2 Influence of heat input on joint strength in laser beam joining of AA5754 alloy and galvanized DP980 steel sheets ${ }^{24)}$ 
improved to $220 \mathrm{~N} \mathrm{~mm}^{-1}$ due to enhancement of wettability of filler deposit on the steel surface, and maximum heat input of $168 \mathrm{~J} \mathrm{~mm}^{-1}$ resulted in formation of greater amount of brittle intermetallic compounds and consequently reduced the joint strength to $137 \mathrm{~N} \mathrm{~mm}^{-1}$. Sun et al. ${ }^{25,26)}$ employed AA4043 filler wire to join 2.5 mm thick AA6061 alloy and electrogalvanized steel sheets by fiber laser beam in butt joint configuration. The authors reported to contain the phase layer thickness in the range of $1.8 \sim 6.2 \mu \mathrm{m}$ with joint strength of 174.64 $\mathrm{MPa}^{25,26)}$.

Thomy et al. ${ }^{11)}$ used heat input range of $47 \sim 56 \mathrm{~J} \mathrm{~mm}^{-1}$ to join $1.15 \mathrm{~mm}$ thick AA6016 alloy and $1 \mathrm{~mm}$ thick DC05 galvanized steel sheets by laser-GMA hybrid source using AA4047 filler wire. The authors found phase layer thickness around $4 \sim 12 \mu \mathrm{m}$ and the maximum joint strength of $180 \mathrm{MPa}^{11)}$. Gao et al. ${ }^{27)}$ joined AA6061 alloy to AISI304 stainless steel, both of $2 \mathrm{~mm}$ thickness, using laser-CMT hybrid technique with AA4047 filler wire. The authors found that a heat input range of $80 \sim 110 \mathrm{~J} \mathrm{~mm}^{-1}$ could contain the phase layer thickness within the range of $3 \sim 6.5 \mu \mathrm{m}$ with the maximum joint strength of $130 \mathrm{MPa}^{27)}$.

In contrast to the laser-GMA hybrid process, Yan et al. $^{28)}$ employed both continuous and pulsed mode dual laser beam for joining of $1.2 \mathrm{~mm}$ thick AA6111 alloy and $0.8 \mathrm{~mm}$ thick low carbon steel sheets without any filler wire, and found the layer thickness around $10 \mu \mathrm{m}$ with the maximum joint strength of $128 \mathrm{MPa}$. In another study, Frank ${ }^{29)}$ used a combined pulsed and continuous laser beam to join $1 \mathrm{~mm}$ thick aluminium alloy and $0.75 \mathrm{~mm}$ thick GI sheets in both lap and flange joint configurations by AA4043, AA4047 and Zn-12\%Al filler wires. The author reported maximum joint strength in the range of $180 \sim 220 \mathrm{MPa}$ with all three types of filler wires in both the lap and the flange configurations. Ma et al. ${ }^{30)}$ attempted to join $1 \mathrm{~mm}$ thick AA6061 alloy and $0.8 \mathrm{~mm}$ thick galvanized DP590 steel using a two-pass laser beam technique without any filler wire. The authors could contain the phase layer thickness around 5 $\mu \mathrm{m}$ with maximum joint strength of $158 \mathrm{~N} \mathrm{~mm}^{-1}$. While, Windmann et al. ${ }^{31)}$ used a Al-Si3-Mn filler wire to join both $1.5 \mathrm{~mm}$ thick AA6016 alloy and aluminized steel sheets considering a higher heat input range of $240 \sim$ $330 \mathrm{~J} \mathrm{~mm}^{-1}$. The maximum joint strength was reported to be $175 \mathrm{MPa}$ for phase layer thickness of $2 \sim 7 \mathrm{\mu m}^{31)}$. In contrast, Borrisutthekul et al. ${ }^{32)}$ reported wider range of heat input of $225 \sim 900 \mathrm{~J} \mathrm{~mm}^{-1}$ in laser beam lap joining of $1.6 \mathrm{~mm}$ thick AA6022 alloy to $1.2 \mathrm{~mm}$ thick steel sheets using different backing plates. Pardal et al. ${ }^{33)}$ spot welded $1 \mathrm{~mm}$ thick AA6111 alloy and DC04 uncoated low carbon steel sheets using conduction mode defocused laser beam in lap joint geometry. The authors reported to contain layer thickness around $10 \mu \mathrm{m}$ with maximum joint strength of $130 \mathrm{MPa}$. Huang et al. ${ }^{34)}$ joined $2 \mathrm{~mm}$ thick 5A02 alloy and $1 \mathrm{~mm}$ thick GI steel sheets without any filler wire by laser-GTA hybrid process. The maximum joint strength was found to be around $163 \mathrm{MPa}$ at phase layer thickness of $8.7 \mu \mathrm{m}$ and corresponding heat input of $136.8 \mathrm{~J} \mathrm{~mm}^{-1}$. In another study, Cui et al. ${ }^{35)}$ employed dual laser beam for joining low carbon steel and AA6061 alloy, both of $1.5 \mathrm{~mm}$ in thickness, without any filler wire. The authors reported the maximum joint strength of $110.6 \mathrm{~N} \mathrm{~mm}^{-1}$ with the separation distance between the laser beam as $1.5 \mathrm{~mm}$ and power distribution ratio as $0.67^{35)}$. Table 1 shows the ranges of employed heat input, growth of phase layer thickness and achieved joint strength in joining of aluminium to steel sheet by laser beam based and laser arc hybrid processes.

\section{Gas Metal Arc Based Joining}

Several researchers have attempted joining of aluminium and steel sheets using pulsed current GMA based process using Al-Si filler wires. Murakami et al. ${ }^{12)}$ used a flux cored AA4047 filler wire to join $2 \mathrm{~mm}$ thick pure aluminium alloy and uncoated steel sheets using a heat input range of $170 \sim 255 \mathrm{~J} \mathrm{~mm}^{-1}$. The maximum joint strength was reported to be $80 \mathrm{MPa}$ with phase layer thickness around $0.9 \sim 2.5 \mu^{12)}$. Park et al. ${ }^{36)}$ used AC pulsed GMA process to join $1.4 \mathrm{~mm}$ thick uncoated steel and $1.6 \mathrm{~mm}$ thick AA6K21 alloy by AA4043 filler wire. The phase layer thickness was contained within $1.14 \sim 3.2 \mu \mathrm{m}$ and the maximum joint strength was achieved as $173 \mathrm{MPa}^{36)}$.

$\mathrm{Su}$ et al. ${ }^{13,14)}$ examined the effect of four different filler wires - pure aluminium, AA4043, AA4047 and AA5356 (Al-5\%Mg) wire - to join AA5052 alloy and GI steel sheets, both in $1 \mathrm{~mm}$ thickness, using a AC doublepulsed GMA technique with heat input of $111 \mathrm{~J} \mathrm{~mm}^{-1}$. Pure aluminium and Al-Mg filler wires exhibited a constant phase layer thickness of around $30 \mu \mathrm{m}^{14)}$. The layer thickness reduced to $1 \sim 7 \mu \mathrm{m}$ when Al-Si filler wires were used ${ }^{13,14)}$. The joints made with the pure aluminium and $\mathrm{Al}-\mathrm{Mg}$ filler wires exhibited lower failure strengths of respectively 165 and $112 \mathrm{MPa}$, and the same with the Si-based wires was around $201 \mathrm{MPa}^{13,14)}$. In another study, Shi et al. ${ }^{37,38)}$ and Shao et al. ${ }^{39)}$ used pulsed current double-electrode GMA technique to examine the effect of AA4043 and AA5356 filler wires in joining both of $1 \mathrm{~mm}$ thick AA5052 alloy and GI sheets. The maximum joint strength with the Al-Si filler wire was reported to be around $199 \mathrm{MPa}^{37)}$. The joints 
Table 1 The ranges of employed heat input, growth of phase layer thickness and achieved joint strength in joining of aluminium to steel by laser beam based and laser-arc hybrid joining processes

\begin{tabular}{|c|c|c|c|c|c|c|c|}
\hline Process & $\begin{array}{l}\text { Al Alloy, } \\
t_{\mathrm{Al}}(\mathrm{mm})\end{array}$ & Steel, $\mathrm{t}_{\mathrm{st}}(\mathrm{mm})$ & $\begin{array}{c}\text { H.I } \\
\left(\mathrm{J} \mathrm{mm}^{-1}\right)\end{array}$ & Filler wire & $\mathrm{d}_{\mathrm{P}}(\mu \mathrm{m})$ & Strength & Reference \\
\hline \multirow{12}{*}{ Laser } & AA6016, 1 & GI, 1.2 & $102 \sim 150$ & AA4047 & 2 & $190 \mathrm{MPa}$ & Sierra et al. ${ }^{10)}$ \\
\hline & Al alloy & GI & $50 \sim 60$ & $\mathrm{Zn}-15 \% \mathrm{Al}$ & 5 & $193 \sim 230 \mathrm{~N} \mathrm{~mm}^{-1}$ & Mathieu et al. ${ }^{17)}$ \\
\hline & AA6016, 1.2 & GI, 0.77 & $60 \sim 110$ & $\mathrm{Zn}-15 \% \mathrm{Al}$ & $8 \sim 12$ & $200 \mathrm{MPa}$ & Dharmendra et al. ${ }^{18}$ \\
\hline & AA6016, 1.2 & GI, 0.7 & 45 & $\mathrm{Zn}-30 \% \mathrm{Al}$ & 10 & $190 \mathrm{MPa}$ & Shabadi et al. ${ }^{19)}$ \\
\hline & AA6016, 1.15 & GI, 1.2 & $138 \sim 156$ & AA4043 & $1.5 \sim 13$ & $162 \mathrm{MPa}$ & Zhang et al. $^{20)}$ \\
\hline & AA6022, 1.2 & GI and GA, 0.8 & - & AA4047 & $2 \sim 3$ & $180 \mathrm{~N} \mathrm{~mm}^{-1}$ & Saida et al. $^{23)}$ \\
\hline & AA5754, 2 & DP980, 1 & $70 \sim 168$ & AA4047 & - & $137 \sim 220 \mathrm{~N} \mathrm{~mm}^{-1}$ & Yang et al. $^{24)}$ \\
\hline & AA6061, 2.5 & Electro-GI, 2.5 & - & AA4043 & $1.8 \sim 6.2$ & 174.64 MPa & Sun et al. ${ }^{25,26)}$ \\
\hline & AA6111, 1.2 & Low carbon, 0.8 & - & - & 10 & $128 \mathrm{MPa}$ & Yan et al. $^{28)}$ \\
\hline & Al alloy, 1 & GI, 0.75 & - & $\begin{array}{l}\text { AA4043, } \\
\text { AA4047, } \\
\text { Zn- } 12 \% \text { Al }\end{array}$ & - & $180 \sim 220 \mathrm{MPa}$ & Frank $^{29)}$ \\
\hline & AA6061, 1 & DP590, 0.8 & - & - & 5 & $158 \mathrm{~N} \mathrm{~mm}^{-1}$ & Ma et $\mathrm{al}^{30)}$ \\
\hline & AA6016, 1.5 & Aluminized steel, 1.5 & $240 \sim 330$ & Al-Si3-Mn & $2 \sim 7$ & $175 \mathrm{MPa}$ & Windmann et al. ${ }^{31)}$ \\
\hline Laser-spot & AA6111, 1 & Uncoated DC04, 1 & - & - & 10 & $130 \mathrm{MPa}$ & Pardal et al. ${ }^{33)}$ \\
\hline \multirow{3}{*}{$\begin{array}{c}\text { Laser-GMA } \\
\text { hybrid }\end{array}$} & AA6016, 1.15 & $\mathrm{DC} 05,1$ & $47 \sim 56$ & AA4047 & $4 \sim 12$ & $180 \mathrm{MPa}$ & Thomy et al. ${ }^{11)}$ \\
\hline & AA6013, 1 & GI, 2 & - & - & $2 \sim 4$ & $247 \mathrm{MPa}$ & Qin et $\mathrm{al}^{21,22)}$ \\
\hline & AA6061, 2 & AISI304, 2 & $80 \sim 110$ & AA4047 & $3 \sim 6.5$ & $130 \mathrm{MPa}$ & Gao et al. ${ }^{27)}$ \\
\hline $\begin{array}{c}\text { Laser-GTA } \\
\text { hybrid }\end{array}$ & $5 \mathrm{~A} 02,2$ & GI, 1 & 136.8 & - & 8.7 & 136.8 & Huang et al. ${ }^{34)}$ \\
\hline
\end{tabular}

H.I - Heat input, $d_{\mathrm{P}}-$ phase layer thickness, $t_{\mathrm{Al}}$ - aluminium sheet thickness, $\mathrm{t}_{\mathrm{St}}-$ steel sheet thickness

that were made with the Al-Mg filler wire had resulted in higher thickness of phase layer as compare to that achieved with the Al-Si filler wire and lower joint strength of $188 \mathrm{MPa}^{37)}$.

Several researchers also studied the effect of galvanized coating on the quality of pulsed current GMA based joining of aluminium alloys and coated steel sheets. Yagati et al. ${ }^{40)}$ joined $2 \mathrm{~mm}$ thick AA6061 alloy and $1.2 \mathrm{~mm}$ thick GI, GA and uncoated steel sheets using a heat input of $62.75 \mathrm{~J} \mathrm{~mm}^{-1}$ with AA4043 filler wire. The joint strength with the GI sheets was reported around $180 \mathrm{~N} \mathrm{~mm}^{-1}$ as compared to 120 and $110 \mathrm{~N}$ $\mathrm{mm}^{-1}$ respectively with the GA and uncoated steel sheets ${ }^{40)}$. The authors attributed the lower phase layer thickness and greater joint strength for the GI steel sheets due to the superior wetting on unmelted steel sheets ${ }^{40)}$. While, Zhang and $\mathrm{Liu}^{15)}$ studied joining of aluminium alloy to hot-dip aluminized and GI stainless steel sheets, all in $1 \mathrm{~mm}$ thickness, by pulsed current GMA technique using AA4043 filler wire with suitable ranges of heat input of $63 \sim 120 \mathrm{~J} \mathrm{~mm}^{-1}$. The aluminium to GI steel joints exhibited a continuous bead, whereas the aluminium and the aluminized steel sheets failed to produce any joint ${ }^{15)}$. Fig. 3 shows variation of heat input and joint strength in GMA joining of aluminiu to GI sheets as reported in Ref. [15]. Fig. 3 illustrates joint strength is increasing from 168 to $194 \mathrm{MPa}$ with an increase in heat input from 63 to $86 \mathrm{~J} \mathrm{~mm}^{-1}$. Further increase in heat input to $120 \mathrm{~J} \mathrm{~mm}^{-1}$ reduced strength to $169 \mathrm{MPa}$. The joints with the GI sheets exhibited phase layer thickness around $5 \sim 15 \mu \mathrm{m}$ with maximum joint strength of $194 \mathrm{MPa}$, while layer thickness of $10 \mu \mathrm{m}$ with failure strength of $60 \mathrm{MPa}$ was found with the alu-

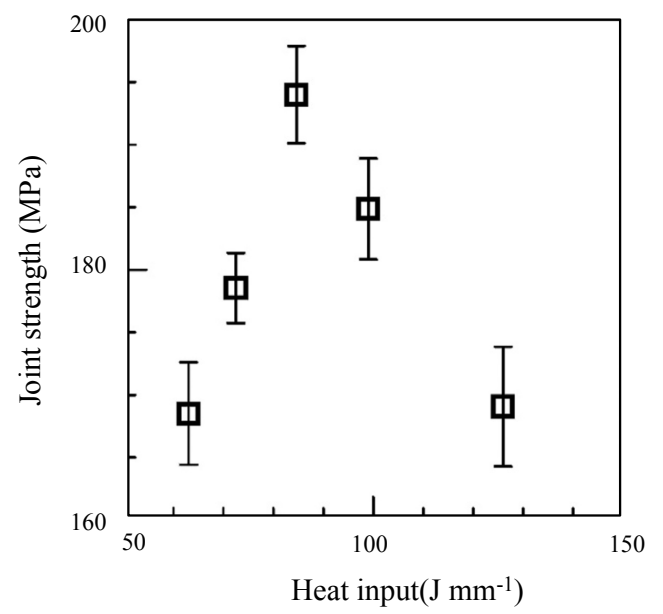

Fig. 3 Comparison of heat input and joint strength in GMA joining of aluminium to GI sheets ${ }^{15}$ ) 


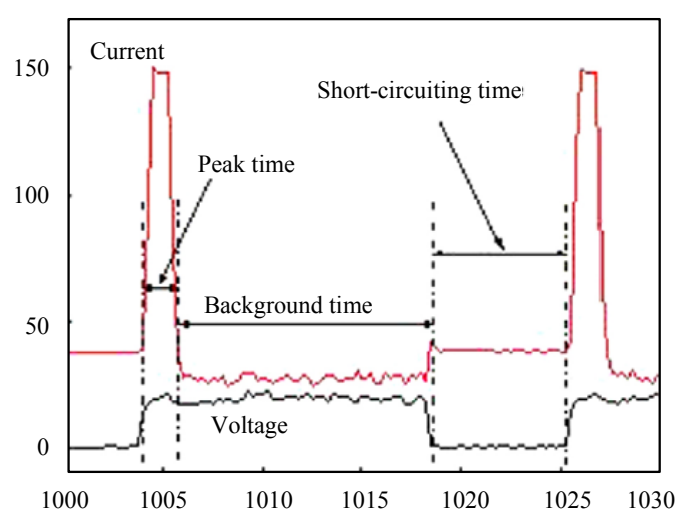

Fig. 4 The current and voltage waveform of CMT pro$\operatorname{cess}^{41)}$

minized steel sheets ${ }^{15)}$.

Zhang et al. ${ }^{41)}$ used Cold Metal Transfer (CMT), a pulsed current GMA technique with short-circuiting metal transfer, to join $1 \mathrm{~mm}$ thick AA1060 and $0.6 \mathrm{~mm}$ thick GI sheets in lap joint configuration using AA4043 filer wire. Fig. 4 depicts the current and voltage transients in a typical CMT process as reported by the authors ${ }^{41)}$. Following points are worth noting from Fig. $4^{41)}$.

- The peak current phase is represented by a constant arc voltage and a high current pulse that was envisaged to facilitate the formation of a droplet at the tip of filler wire,

- In the background phase, the current was reduced and kept constant till the beginning of the short-circuiting period to decrease the arc power and inhibit globular transfer of droplet from the filler wire tip,

- During the short circuiting phase the filler wire dipped into the melt pool causing the arc to extinguish and the voltage reduced to zero. A backward movement of the filler wire at this stage is provided to assist the detachment of the droplet from the filler wire into the melt pool without the aid of electromagnetic force. The arc reignite at the end of short circuiting phase $^{41)}$.

The authors reported phase layer thickness around $4 \mu \mathrm{m}$ with maximum joint strength of $83 \mathrm{MPa}^{41)}$. Agudo et al. $^{5)}$ used the CMT process to join $1 \mathrm{~mm}$ thick AA6016 alloy and hot dip galvanized steel sheets with AA1080 (Al $99.8 \%$ ) filler wire and found phase layer thickness of $2.3 \mu \mathrm{m}$ at the joint interface. In another study, Zhang et al. ${ }^{42,43)}$ used AA4043 filler wire to join both of $1 \mathrm{~mm}$ thick aluminium alloy and GI sheets by the CMT process with a heat input range of around $55 \sim 91 \mathrm{~J} \mathrm{~mm}^{-1}$. The authors reported phase layer thickness around $7 \sim$ $40 \mu \mathrm{m}$ and achieved the maximum joint strength of 96 $\mathrm{MPa}^{42,43)}$. Cao et al. ${ }^{6}$ achieved a smooth joint bead in joining of AA6061 alloy and GI sheets, both in $1 \mathrm{~mm}$ thickness, using the CMT process with AA4043 filler wire and higher heat input of $200 \mathrm{~J} \mathrm{~mm}^{-1}$. The authors achieved maximum joint strength of $200 \mathrm{MPa}$ by containing the phase layer thickness within $3 \sim 5 \mu \mathrm{m}^{6}$ ). Kang and $\mathrm{Kim}^{44)}$ employed typical heat input of $112 \mathrm{~J} \mathrm{~mm}^{-1}$ to join AA5052 alloy with hot dip aluminized and with GI steel sheets in the thickness ranges of 1 to $1.2 \mathrm{~mm}$ by CMT process using AA4043, AA4047, AA5183 and AA5356 filler wires. The authors found phase layer thickness around $5 \mu \mathrm{m}$ with Al-Si filler wire while the $\mathrm{Al}-\mathrm{Mg}$ filler wire resulted in higher the phase layer thickness of $12 \sim 13 \mu \mathrm{m}^{44)}$.

Das et al. ${ }^{7,45,46)}$ used a wide range of heat input from $36 \sim 126 \mathrm{~J} \mathrm{~mm}^{-1}$ for joining of aluminium alloy to GI and GA steel sheets by coldArc, a low heat input pulsed current GMA process. Fig. 5 shows the current and voltage waveform of coldArc process and following points are noting $^{7)}$

- The short-circuiting period $\left(\mathrm{t}_{\mathrm{S}}\right)$ began with rapid increase in welding current and drop of voltage to a very small value.

- At the end of the short-circuiting period, the current was reduced to a small value to shear-off the molten metal from liquid bridge at a low power resulting in reduction of spatter.

- In arcing period $\left(\mathrm{t}_{\mathrm{A}}\right)$, a peak current pulse was applied for a very short duration to facilitate the formation of droplet at the tip of filler wire. Current was reduced further and kept constant until the droplet formed a liquid bridge with molten pool.

The authors found a profound dependence of heat input with phase layer thickness and joint strength. Fig. 6 shows variation of phase layer thickness and joint strength with heat input in joining of AA5754 alloy and GI sheets. Fig. 6(a) shows phase layer thickness is increasing from 0.52 to $3.73 \mu \mathrm{m}$ with rise in heat input from 36 to $68 \mathrm{~J} \mathrm{~mm}^{-1}$. Fig. 6(b) depicts an increase in

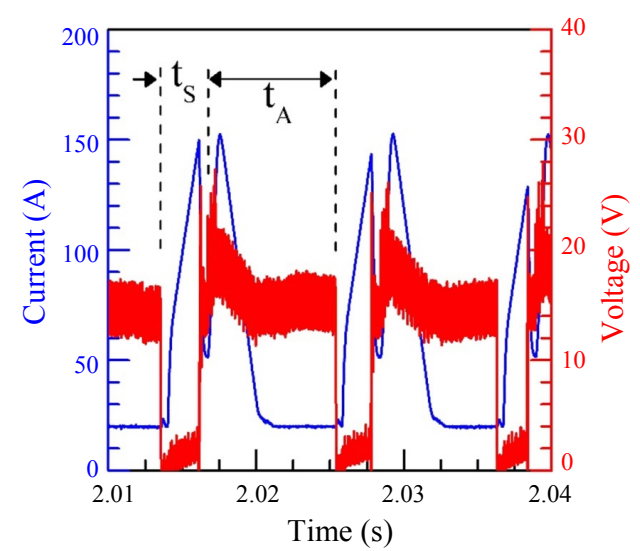

Fig. 5 Current and voltage waveform of coldArc pro$\operatorname{cess}^{7)}$ 

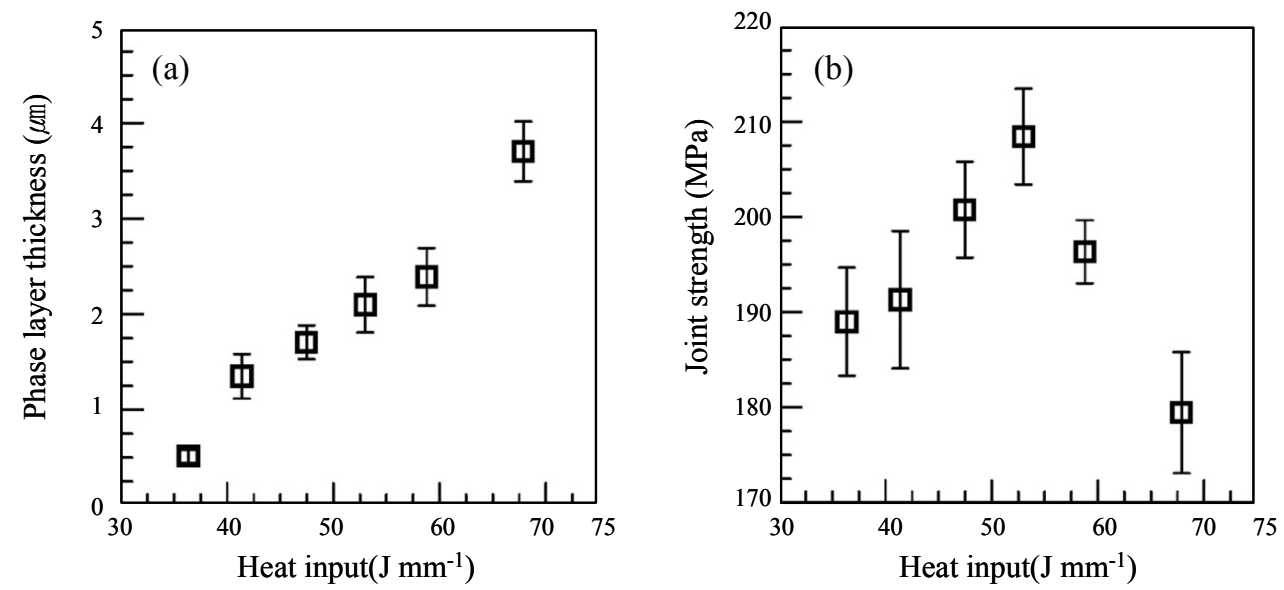

Fig. 6 Variation of heat input with (a) phase layer thickness and (b) joint strength in GMA joining of AA5754 alloy and GI sheets ${ }^{7)}$

heat input from 36 to $53 \mathrm{~J} \mathrm{~mm}^{-1}$ increases corresponding joint strength from 188 to $206 \mathrm{MPa}$, and further rise in heat input decreases joint strength to $180 \mathrm{MPa}^{7)}$. The authors found phase layer thickness around $1.3 \sim 2 \mu \mathrm{m}$ with maximum joint strength of $73 \mathrm{MPa}$ for aluminium to GA sheets ${ }^{45,46)}$, while joining with GI sheet exhibited higher joint strength of $210 \mathrm{MPa}$ with phase layer thickness of $0.8 \sim 4.5 \mu \mathrm{m}^{7)}$.

Milani et al. ${ }^{47)}$ examined the influence of different filler wires - AA4043, AA4047 and Al-Si3-Mn - on joining of $2 \mathrm{~mm}$ thick AA5754 alloy and $3 \mathrm{~mm}$ thick GI steel sheets by CMT process. The maximum joint strength was found to be around $188 \mathrm{MPa}$ with the Al-Si3-Mn1 filler wire ${ }^{47)}$. In another study, Chang et al. ${ }^{48)}$ investigated the effect of AA2319 (Al-6\%Cu) and AA5087 $(\mathrm{Al}-5 \% \mathrm{Mg})$ filler wire on joint quality in joining of AA6082 and ultra-high strength steel, both of $4 \mathrm{~mm}$ in thickness, by GMA process. The authors found Al- $\mathrm{Cu}$ filler wire exhibited lower phase layer thickness around $2 \sim 4 \mu \mathrm{m}$ while Al-Mg filler wire resulted layer thickness of $6 \sim 18 \mu \mathrm{m}^{48)}$. The maximum joint strength was reported to be around $128 \mathrm{MPa}$ using $\mathrm{Al}-\mathrm{Cu}$ filler wire $^{48)}$

Ma et al. $^{49)}$ employed different pre-heating temperature to join $1 \mathrm{~mm}$ thick AA5052 alloy and $2 \mathrm{~mm}$ thick GI sheet by pulsed current GMA process using heat input rage of $54.6 \sim 110.5 \mathrm{~J} \mathrm{~mm}^{-1}$ and AA4043 filler wire. The author reported pre-heating temperature had direct influence on growth of phase layer thickness. The authors found phase layer thickness in the range of $1 \sim 10 \mu \mathrm{m}$ and achieved maximum joint strength around $162 \mathrm{MPa}$ for pre-heat temperature of $373 \mathrm{~K}^{49}$. Madhavan et al. ${ }^{50)}$ used heat input rage of $110 \sim 140 \mathrm{~J} \mathrm{~mm}^{-1}$ for joining 2 mm thick AA6061 alloy and $1.6 \mathrm{~mm}$ thick DP800 steel sheets by CMT process with AA4043 filler wire. The corresponding phase layer thickness and the maximum joint strength were reported to be $1.23 \sim 3.02 \mu \mathrm{m}$ and $440 \mathrm{~N} \mathrm{~mm}^{-1}$, respectively ${ }^{50)}$.

Ye et al. ${ }^{51,52)}$ achieved excellent joint bead using GMAGTA double sided arc process in joining AA5052 alloy and low carbon steel, both of $3 \mathrm{~mm}$ in thickness, with AA4043 filler wire and considering heat input of 85.8 $\mathrm{J} \mathrm{mm}^{-1}$. The author found lower layer thickness of 2.03 um using double sided arc process while conventional GMA process exhibited layer thickness of $4.03 \mu \mathrm{m}$. The maximum joint strength in double sided arc process was reported to be $148.1 \mathrm{MPa}$, which was 2.5 times than that of the traditional GMA process ${ }^{51)}$. Table 2 illustrates a brief summary of heat input and flier wire composition on the joint strength and formation of intermetallic phase layer in GMA based joining of aluminium and steel sheets.

Experimental investigations on joining of aluminium to steel sheets by laser beam, laser-arc hybrid and GMA based joining processes with different filler wire compositions are presented. The best joint strength could be achieved with a relatively thinner phase layer. The heat input and composition of filler wire were reported to be a crucial factor to control the growth of the phase layer. Furthermore, the $\mathrm{Zn}$ coating in case of galvanized sheets could improve the wetting of the filler wire deposit on the unmelted steel surface and the joint strength.

\section{Influence of Heat Input on Intermetallic Phase Layer Thickness and Joint Strength}

A direct effect of heat input on the formation of thicker phase layer is generally agreed in most of the experimental studies in joining of aluminium and steel using laser beam and GMA based processes. However, the suggested range of heat input for controlling the phase layer thicknesses also varied in the published literature. For example, a heat input range of $47 \sim 110 \mathrm{~J} \mathrm{~mm}^{-1}$ was 
Table 2 Applied heat input, intermetallic phase layer thickness and corresponding joint strength in joining of aluminium to steel by GMA based joining process

\begin{tabular}{|c|c|c|c|c|c|c|c|}
\hline Process & $\begin{array}{l}\text { Al Alloy, } t_{\mathrm{Al}} \\
(\mathrm{mm})\end{array}$ & $\begin{array}{l}\text { Steel, } t_{\text {st }} \\
(\mathrm{mm})\end{array}$ & $\begin{array}{c}\text { H.I } \\
\left(\mathrm{J} \mathrm{mm}^{-1}\right) \\
\end{array}$ & Filler wire & $\mathrm{d}_{\mathrm{P}}(\mu \mathrm{m})$ & Strength & Reference \\
\hline \multirow{6}{*}{ Pulsed GMA } & Al alloy, 2 & Uncoated steel, 2 & $170 \sim 255$ & AA4047 & $0.9 \sim 2.5$ & $80 \mathrm{MPa}$ & Murakami et al. ${ }^{12)}$ \\
\hline & Al alloy, 1 & GI, 1 & $63 \sim 120$ & AA4043 & $5 \sim 15$ & $168 \sim 194 \mathrm{MPa}$ & Zhang and $\mathrm{Liu}^{15)}$ \\
\hline & AA5052, 1 & GI, 1 & - & $\begin{array}{l}\text { AA4043, } \\
\text { AA5356 }\end{array}$ & - & $\begin{array}{c}199 \mathrm{MPa} \\
(\mathrm{AA} 4043), \\
188 \mathrm{MPa} \\
(\mathrm{AA} 5356)\end{array}$ & $\begin{array}{l}\text { Shi et al. }{ }^{37,38)} \text {, } \\
\text { Shao et al. }{ }^{39)}\end{array}$ \\
\hline & AA6061, 2 & $\begin{array}{c}\text { GI, GA and } \\
\text { uncoated steel, } 1.2\end{array}$ & 62.75 & AA4043 & - & $\begin{array}{l}110 \sim 180 \\
\mathrm{~N} \mathrm{~mm}^{-1}\end{array}$ & Yagati et al. ${ }^{40)}$ \\
\hline & AA6082, 4 & UHSS, 4 & - & $\begin{array}{l}\text { AA2319, } \\
\text { AA5087 }\end{array}$ & $\begin{array}{c}2 \sim 4 \\
(\mathrm{AA} 2319) \\
6 \sim 18 \\
(\mathrm{AA} 5087) \\
\end{array}$ & $\begin{array}{c}128 \mathrm{MPa} \\
\text { (AA2319), } \\
65 \mathrm{MPa} \\
\text { (AA5087) }\end{array}$ & Chang et $\mathrm{al}^{48)}$ \\
\hline & AA5052, 1 & GI, 2 & $54.6 \sim 110.5$ & AA4043 & $1 \sim 10$ & $162 \mathrm{MPa}$ & Ma et al. $^{49)}$ \\
\hline $\begin{array}{l}\text { AC pulsed } \\
\text { GMA }\end{array}$ & AA6021, 1.6 & Uncoated steel, 1.4 & - & AA4043 & $1.14 \sim 3.2$ & $173 \mathrm{MPa}$ & Park et al. ${ }^{36)}$ \\
\hline $\begin{array}{c}\text { AC } \\
\text { Double-pulsed } \\
\text { GMA }\end{array}$ & AA5052, 1 & GI, 1 & 111 & $\begin{array}{l}\text { Pure Al } \\
\text { AA4043, } \\
\text { AA4047, } \\
\text { AA5356 }\end{array}$ & $\begin{array}{c}1 \sim 7 \\
(\mathrm{AA} 4043, \\
\text { AA4047), } \\
\sim 30 \\
\text { (pure Al, } \\
\text { AA5356) }\end{array}$ & $\begin{array}{c}112 \mathrm{MPa} \\
(\mathrm{AA} 5356), \\
165 \mathrm{MPa} \\
(\text { Pure } \mathrm{Al}), \\
201 \mathrm{MPa} \\
(\mathrm{AA} 4043, \\
\text { AA4047) }\end{array}$ & Su et al. ${ }^{13,14)}$ \\
\hline $\begin{array}{l}\text { Double sided } \\
\text { arc joining }\end{array}$ & AA5052, 3 & Low carbon steel, 3 & 85.8 & AA4043 & 2.03 & $148.1 \mathrm{MPa}$ & Ye et al. ${ }^{51)}$ \\
\hline \multirow{7}{*}{ CMT } & AA6016, 1 & GI, 1 & - & AA1080 & 2.3 & - & Agudo et al. ${ }^{5)}$ \\
\hline & AA6061, 1 & GI, 1 & 200 & AA4043 & $3 \sim 5$ & $200 \mathrm{MPa}$ & Cao et al. ${ }^{6}$ \\
\hline & AA1060, 1 & GI, 0.6 & - & AA4043 & 4 & $83 \mathrm{MPa}$ & Zhang et al. ${ }^{41)}$ \\
\hline & Al alloy, 1 & GI, 1 & $55 \sim 91$ & AA4043 & $7 \sim 40$ & $96 \mathrm{MPa}$ & Zhang et al. $^{42,43)}$ \\
\hline & AA5052, 1 & $\begin{array}{l}\text { Al-coated } \\
\text { and GI, } 1.2\end{array}$ & 111 & $\begin{array}{l}\text { AA4043, } \\
\text { AA4047, } \\
\text { AA5183, } \\
\text { AA5356 }\end{array}$ & $\begin{array}{c}5 \\
\text { (Al-Si filler), } \\
12 \sim 13 \\
\text { (Al-Mg filler) }\end{array}$ & $\begin{array}{c}75 \sim 188 \\
\mathrm{MPa}\end{array}$ & Kang and $\mathrm{Kim}^{44)}$ \\
\hline & AA5754, 2 & GI, 3 & - & \begin{tabular}{|l} 
AA4043 \\
AA4047, \\
Al-Si3-Mn \\
\end{tabular} & - & $188 \mathrm{MPa}$ & Milani et al. ${ }^{47)}$ \\
\hline & AA6061, 2 & DP800, 1.6 & $110 \sim 140$ & AA4043 & $1.23 \sim 3.02$ & $440 \mathrm{~N} \mathrm{~mm}^{-1}$ & Madhavan et al. ${ }^{50)}$ \\
\hline coldArc & $\begin{array}{c}\text { AA5754 and } \\
\text { AA5052, } \\
1 \sim 1.5\end{array}$ & $\begin{array}{l}\text { GI and GA, } \\
\quad 1 \sim 1.2\end{array}$ & $36 \sim 126$ & AA4043 & $0.8 \sim 4.5$ & $\begin{array}{c}210 \mathrm{MPa}(\mathrm{GA}) \\
73 \mathrm{MPa}(\mathrm{GA})\end{array}$ & Das et al. ${ }^{7,45,46)}$ \\
\hline
\end{tabular}

UHSS - ultra-high strength steel

reported to contain the phase layer thickness within $4 \sim$ $8 \mu \mathrm{m}$ and resulted joint strength around $96 \sim 200 \mathrm{MPa}$ in GMA $^{15,41,42,49)}$, laser beam ${ }^{18)}$ and laser-arc hybrid ${ }^{11)}$ joining of aluminium and steel with $\mathrm{Al}-\mathrm{Si}^{11,15,41,42)}$ and $\mathrm{Zn}-\mathrm{Al}^{18)}$ based filler wires. In contrast, typical phase layer thickness of $2 \sim 7 \mu \mathrm{m}$ and corresponding joint strength around $200 \mathrm{MPa}$ were reported for a heat input range of $111 \sim 150 \mathrm{~J} \mathrm{~mm}^{-1}$ in GMA, ${ }^{13,14,44)}$ and laser beam $^{10,20)}$ joining of aluminium and steel with pure $\mathrm{Al}^{13)}$, and $\mathrm{Al}-\mathrm{Si}^{10,13,14,20,44)}$ based filler wires. Even a higher heat input range of $170 \sim 330 \mathrm{~J} \mathrm{~mm}^{-1}$ resulted in typical phase layer thickness around $0.9 \sim 7 \mu \mathrm{m}$ and joint strength around $80 \sim 200 \mathrm{MPa}$ in $\mathrm{GMA}^{6,12)}$ and laser beam $^{31)}$ based joining of aluminium and steel with $\mathrm{Al}-\mathrm{Si}^{6,12,31)}$ based filler wires. In contrast, a lower heat input range of $56 \sim 156 \mathrm{~J} \mathrm{~mm}^{-1}$ was found to result in the formation of thick layer of $12 \sim 20 \mu \mathrm{m}$ and joint strength of $200 \mathrm{MPa}$ in laser beam ${ }^{18,20)}$ and laser-arc hy- 
Table 3 Filler wire composition on intermetallic phase layer thickness and the final joint strength for laser beam and GMA based joining processes

\begin{tabular}{|c|c|c|c|c|}
\hline Filler wire & $\mathrm{d}_{\mathrm{p}}(\mu \mathrm{m})$ & Strength & Process & Reference \\
\hline \multirow{2}{*}{ Pure Al } & 2.3 & - & $\mathrm{CMT}$ & Agudo et al. ${ }^{5)}$ \\
\hline & $2 \sim 7$ & $165 \mathrm{MPa}$ & AC double pulsed GMA & Su et al. ${ }^{13,14)}$ \\
\hline \multirow{12}{*}{ AA4043 } & $3 \sim 5$ & $200 \mathrm{MPa}$ & $\mathrm{CMT}$ & Cao et al. ${ }^{6)}$ \\
\hline & $0.8 \sim 4.5$ & $210 \mathrm{MPa}$ & coldArc & Das et al. ${ }^{7)}$ \\
\hline & $4 \sim 7$ & $188 \mathrm{MPa}$ & AC double pulsed GMA & $\mathrm{Su}$ et $\mathrm{al}^{13,14)}$ \\
\hline & $5 \sim 15$ & $194 \mathrm{MPa}$ & Pulsed GMA & Zhang and $\mathrm{Liu}^{15)}$ \\
\hline & $1.14 \sim 3.2$ & $173 \mathrm{MPa}$ & Pulsed GMA & Park et al. ${ }^{36)}$ \\
\hline & - & $199 \mathrm{MPa}$ & Pulsed GMA & Shi et al. ${ }^{37,38)}$, Shao et al. ${ }^{39)}$ \\
\hline & 4 & $83 \mathrm{MPa}$ & CMT & Zhang et $\mathrm{al}^{41)}$ \\
\hline & $7 \sim 20$ & $96 \mathrm{MPa}$ & CMT & Zhang et al. ${ }^{42,43)}$ \\
\hline & $1 \sim 10$ & $162 \mathrm{MPa}$ & CMT & Ma et al. $^{49)}$ \\
\hline & 2.03 & $148 \mathrm{MPa}$ & Double side arc joining & Ye et al. $^{51)}$ \\
\hline & $1.5 \sim 13$ & $162 \mathrm{MPa}$ & Laser & Zhang et al. $^{20)}$ \\
\hline & $1.8 \sim 6.2$ & $174.64 \mathrm{MPa}$ & Laser & Sun et al. $^{25)}$ \\
\hline \multirow{7}{*}{ AA4047 } & $0.9 \sim 2.5$ & $80 \mathrm{MPa}$ & Pulsed GMA & Murakami et al. ${ }^{12)}$ \\
\hline & $1 \sim 4$ & $201 \mathrm{MPa}$ & AC double pulsed GMA & Su et al. $^{13,14)}$ \\
\hline & 5 & $175 \mathrm{~N} \mathrm{~mm}^{-1}$ & CMT & Kang and $\mathrm{Kim}^{44)}$ \\
\hline & 2 & $190 \mathrm{MPa}$ & Laser & Sierra et al. ${ }^{10)}$ \\
\hline & $2 \sim 3$ & $180 \mathrm{~N} \mathrm{~mm}^{-1}$ & Laser & Saida et al. $^{23)}$ \\
\hline & $4 \sim 12$ & $180 \mathrm{MPa}$ & Laser - GMA hybrid & Thomy et al. ${ }^{11)}$ \\
\hline & $3 \sim 6.5$ & $130 \mathrm{MPa}$ & Laser - GMA hybrid & Gao et al. ${ }^{27)}$ \\
\hline \multirow{3}{*}{$\begin{array}{c}\mathrm{Zn}-30 \% \mathrm{Al} \text { and } \\
\mathrm{Zn}-15 \% \mathrm{Al}\end{array}$} & 5 & $193 \sim 230 \mathrm{~N} \mathrm{~mm}^{-1}$ & Laser & Mathieu et al. ${ }^{17)}$ \\
\hline & $8 \sim 12$ & $200 \mathrm{MPa}$ & Laser & Dharmendra et al. ${ }^{18)}$ \\
\hline & 10 & $190 \mathrm{MPa}$ & Laser & Shabadi et al. ${ }^{19)}$ \\
\hline \multirow{2}{*}{$\begin{array}{c}\text { AA5183 and } \\
\text { AA5356 }\end{array}$} & $\sim 30$ & $112 \mathrm{MPa}$ & AC double pulsed GMA & Su et al. ${ }^{13,14)}$ \\
\hline & $12 \sim 13$ & $188 \mathrm{MPa}$ & CMT & Kang and $\mathrm{Kim}^{44)}$ \\
\hline
\end{tabular}

brid $^{11)}$ joining of aluminium and steel with $\mathrm{Al}^{-\mathrm{Si}^{11,20)}}$ and $\mathrm{Zn}-\mathrm{Al}^{18)}$ based filler wires.

\section{Influence of Filler Wires on Intermetallic Phase Layer Thickness and Joint Strength}

In general, pure-Al, Al-Si, $\mathrm{Zn}-\mathrm{Al}$ and $\mathrm{Al}-\mathrm{Mg}$ based filler wires were employed to join aluminium and steel sheets by GMA, laser beam and laser-arc hybrid processes. The pure-Al based filler wires typically resulted in phase layer thickness in the range of $2.3 \sim 7 \mu \mathrm{m}$ and joint strength around $165 \mathrm{MPa}$ in $\mathrm{GMA}^{5,14)}$ based joining techniques. The AA4043 filler wire formed layer thickness in the range of $1 \sim 20 \mu \mathrm{m}$ and corresponding joint strength around $83 \sim 200 \mathrm{MPa}$ in $\mathrm{GMA}^{6,7,13-15,36-39}$, $41-43,49,51)$ and laser beam ${ }^{20,25)}$ based joining processes. In contrast, AA4047 filler wire resulted in phase layer thickness in the range of $0.9 \sim 12 \mu \mathrm{m}$ and joint strength around $80 \sim 200 \mathrm{MPa}$ in $\mathrm{GMA}^{12-14,44)}$, laser beam ${ }^{10,23)}$ and laser-arc hybrid ${ }^{11,27)}$ processes.
The $\mathrm{Zn}$-Al based filler wires, resulted the phase layer thickness in the range of $5 \sim 12 \mu \mathrm{m}$ and joint strength around $200 \mathrm{MPa}$ in laser beam ${ }^{17-19)}$ joining process. In contrast, AA5183 and AA5356 filler wires reported the growth of layer thickness around $7 \sim 13 \mu \mathrm{m}$ and the joint strength of $112 \sim 188 \mathrm{MPa}$ in $\mathrm{GMA}^{13,14,44)}$ based processes. Influence of filler wire composition on intermetallic phase layer thickness and the final joint strength for laser beam and GMA based joining processes is presented in tabular form as Table 3.

\section{Conclusion}

A brief survey of the experimental studies on joining of aluminium and steel sheets using laser beam, laser arc hybrid and GMA based techniques is presented in the above sections. The effect of joining processes such as heat input and filler wire composition on the joint strength and formation of intermetallic phase layer at the joint interface are analyzed in details. The experimental 
studies reported in the literature have shown that the heat input and filler wire composition would primarily influence the growth of phase layer at the joint interface and the final joint strength, irrespective of joining processes. However, the reported studies remained inconclusive about the permissible range of heat input to contain the phase layer thickness. Further, recent advancements in low energy pulsed current GMA techniques with controlled short-circuiting and metal transfer at low power have provided an opportunity to utilize these techniques for the joining of aluminium alloys and galvanized steels at a very low heat input.

\section{Acknowledgement}

The authors would like to thank Prof. Amitava De, IIT Bombay, Mumbai, India for his valuable ideas and suggestions to improve the contents of the present work.

ORCID: Atanu Das: https://orcid.org/0000-0002-7694-4345 ORCID: Hee-Seon Bang: https://orcid.org/0000-0003-4891-5712

\section{References}

1. U. Dilthey and L. Stein, Multimaterial car body design: challenge for welding and joining, Sci. Technol. Weld. Joi, 11(2) (2006), 135-142

https://doi.org/10.1179/174329306X85967

2. J.E. Gould, Joining aluminum sheet in the automotive industry - a 30 year history, Weld. J, 91(1) (2012), $23 \mathrm{~s}-34 \mathrm{~s}$

3. W.S, Miller, L. Zhuang, J. Bottema, A.J. Wittebrood, P.D. Smet, A. Haszler and A. Vieregge, Recent development in aluminium alloys for the automotive industry, Mater. Sci. Eng. A, 280(1) (2000), 37-49 https://doi.org/10.1016/S0921-5093(99)00653-X

4. H.K.D.H. Bhadeshia, Problems in the welding of automotive alloys, Sci. Technol. Weld. Joi, 20(6) (2015), 451-453

https://doi.org/10.1179/15Z.000000000379

5. L. Agudo, D. Eyidi, C.H. Schmaranzer, E. Arenholz, N. Jank, J. Bruckner and A.R. Pyzalla, Intermetallic $\mathrm{Fe}_{\mathrm{x}} \mathrm{Al}_{\mathrm{y}}$ phases in a steel/Al-alloy fusion weld, J. Mater. Sci, 42(12) (2007), 4205-4214

https://doi.org/10.1007/s10853-006-0644-0

6. R. Cao, J.H. Sun, J.H. Chen and P. Wang, Cold metal transfer joining of aluminum alloys-to-galvanized mild steel, J. Mater. Process. Tech, 213(10) (2013), 1753-1763 http://dx.doi.org/10.1016/j.jmatprotec.2013.04.004

7. A. Das, M. Shome, S.F. Goecke and A. De, Joining of aluminium alloy and galvanized steel using a controlled gas metal arc process, J. Manuf. Process, 27 (2017), $179-187$

https://doi.org/10.1016/j.jmapro.2017.04.006
8. X. Sun, E.V. Stephens, M.A. Khaleel, H. Shao, and M. Kimchi, Resistance spot welding of aluminum alloy to steel with transition material - from process to performance - part I: experimental study, Weld. J, 83(7) (2004), $188 \mathrm{~s}-195 \mathrm{~s}$

9. T. Watanabe, H. Takayama and A. Yanagisawa, Joining of aluminum alloy to steel by friction stir welding, $J$. Mater. Process. Tech, 178(1-3) (2006), 342-349 https://doi.org/10.1016/j.jmatprotec.2006.04.117

10. G. Sierra, P. Peyre, F.D. Beaume, D. Stuart and G. Fras, Steel to aluminium braze welding by laser process with Al-12Si filler wire, Sci. Technol. Weld. Joi, 13(5) (2008), 430-437 https://doi.org/10.1179/174329308X341852

11. C. Thomy and F. Vollertsen, Laser-MIG hybrid welding of aluminium to steel - effect of process parameters on joint properties, Weld. World, 56(5-6) (2012), 124132 https://doi.org/10.1007/BF03321356

12. T. Murakami, K. Nakata, H. Tong and M. Ushio, Dissimilar metal joining of aluminum to steel by MIG arc brazing using flux cored wire, ISIJ Int, 43(10) (2003), 1596-1602

13. Y. Su, X. Hua and Y. Wu, Effect of input current modes on intermetallic layer and mechanical property of aluminum-steel lap joint obtained by gas metal arc welding, Mater. Sci. Eng. A, 578 (2013), 340-345 https://doi.org/10.1016/j.msea.2013.04.097

14. Y. Su, X. Hua and Y. Wu, Influence in alloy elements on microstructure and mechanical property of aluminum-steel lap joint made by gas metal arc welding, $J$. Mater. Process. Tech, 214(4) (2014), 750-755 https://doi.org/10.1016/j.jmatprotec.2013.11.022

15. H. Zhang and J. Liu, Microstructure characteristics and mechanical property of aluminum alloy/stainless steel lap joints fabricated by MIG welding-brazing process, Mater. Sci. Eng. A, 528(19-20) (2011), 6179-6185 https://doi.org/10.1016/j.msea.2011.04.039

16. I. Lum, S. Fukumoto, E. Biro, D.R. Boomer, and Y. Zhou, Electrode pitting in resistance spot welding of aluminum alloy 5182, Metall. Mater. Trans. A, 35(1) (2004), 217-226 https://doi.org/10.1007/s11661-004-0122-8

17. A. Mathieu, R. Shabadi, A. Deschamps, M. Suery, S. Mattei, D. Grevey and E. Cicala, Dissimilar material joining using laser (aluminum to steel using zinc-based filler wire), Opt. Laser Technol, 39(3) (2007), 652-661 https://doi.org/10.1016/j.optlastec.2005.08.014

18. C. Dharmendra, K.P. Rao, J. Wilden and S. Reich, Study on laser welding-brazing of zinc coated steel to aluminum alloy with a zinc based filler, Mater. Sci. Eng. A. 528(3) (2011), 1497-1503 https://doi.org/10.1016/j.msea.2010.10.050

19. M. Shabadi, A. Suery and A. Deschamps, Characterization of joints between aluminum and galvanized steel sheets, Metall. Mater. Trans. A, 44(6) (2013), 2672-2682 
https://doi.org/10.1007/s11661-012-1605-7

20. M.J. Zhang, G.Y. Chen, Y. Zhang and K.R. Wu, Research on microstructure and mechanical properties of laser keyhole welding-brazing of automotive galvanized steel to aluminum alloy, Mater. Design, 45 (2013), 24-30 https://doi.org/10.1016/j.matdes.2012.09.023

21. G.L. Qin, Y.H. Su and S.H. Wang, Microstructures and properties of welded joint of aluminum alloy to galvanized steel by Nd:YAG laser + MIG arc hybrid brazing-fusion welding, T. Nonferr. Metal Soc, 24(4) (2014), 989-995 https://doi.org/10.1016/S1003-6326(14)63153-8

22. G. Qin, L. Zhen, Y. Su, B. Fu, X. Meng and S. Lin, Large spot laser assisted GMA brazing-fusion welding of aluminum alloy to galvanized steel, J. Mater. Process. Tech, 214(11) (2014), 2684-2692

https://doi.org/10.1016/j.jmatprotec.2014.06.011

23. K. Saida, H. Ohnishi and K. Nishimoto, Fluxless laser brazing of aluminium alloy to galvanized steel using a tandem beam - dissimilar laser brazing of aluminium alloy and steels, Weld. Int, 24(3) (2010), 161-168 https://doi.org/10.1080/09507110902843065

24. J. Yang, Y. Li, H. Zhang, W. Guo, D. Weckman and N. Zhou, Dissimilar laser welding/brazing of 5754 aluminum alloy to DP 980 steel: mechanical properties and interfacial microstructure, Metall. Mater. Trans. A, 46(11) (2015), 5149-5157 https://doi.org/10.1007/s11661-015-3079-X

25. J. Sun, J. Huang, Q. Yan, and Z. Li, Fiber laser butt joining of aluminum to steel using welding - brazing method, Int. J. Adv. Manuf. Tech, 85(9-12) (2015), 26392650 https://doi.org/10.1007/s00170-015-8137-4

26. J. Sun, Q. Yan, W. Gao and J. Huang, Investigation of laser welding on butt joints of $\mathrm{Al} /$ steel dissimilar materials, Mater. Design, 83 (2015), 120-128 https://doi.org/10.1016/j.matdes.2015.05.069

27. M. Gao, C. Chen, S. Mei, L. Wang and X. Zeng, Parameter optimization and mechanism of laser - arc hybrid welding of dissimilar Al alloy and stainless steel, Int. J. Adv. Manuf. Tech, 74(1-4) (2014), 199-208 https://doi.org/10.1007/s00170-014-5996-Z

28. S. Yan, Z. Hong, T. Watanabe and T. Jingguo, CW/PW dual-beam YAG laser welding of steel/aluminum alloy sheet, Opt. Laser. Eng, 48(7-8) (2010), 732-736 https://doi.org/10.1016/j.optlaseng.2010.03.015

29. S. Frank, Flux-free laser joining of aluminum and galvanized steel, J. Mater. Process. Tech, 222 (2015), 365-372

https://doi.org/10.1016/j.jmatprotec.2015.03.032

30. J. Ma, M. Harooni, B. Carlson and R. Kovacevic, Dissimilar joining of galvanized high-strength steel to aluminum alloy in a zero-gap lap joint configuration by two-pass laser welding, Mater. Design, 58 (2014), 390-401 https://doi.org/10.1016/j.matdes.2014.01.046

31. M. Windmann, A. Rottger, H. Kugler, W. Theisen and F. Vollertsen, Laser beam welding of aluminum to Al-base coated high-strength steel 22MnB5, J. Mater. Process. Tech, 217 (2015), 88-95

https://doi.org/10.1016/j.jmatprotec.2014.10.026

32. R. Borrisutthekul, T. Yachi, Y. Miyashita and Y. Mutoh, Suppression of intermetallic reaction layer formation by controlling heat flow in dissimilar joining of steel and aluminium alloy, Mater. Sci. Eng. A, 467(1-2) (2007), 108-113

https://doi.org/10.1016/j.msea.2007.03.049

33. G. Pardal, S. Meco, S. Ganguly, S. Williams and P. Prangnell, Dissimilar metal laser spot joining of steel to aluminium in conduction mode, Int. J. Adv. Manuf. Tech, 73(1-4) (2014), 365-373 https://doi.org/10.1007/s00170-014-5802-y

34. J. Huang, J. He, X. Yu, C. Li, D. Fan, The study of mechanical strength for fusion-brazed butt joint between aluminum alloy and galvanized steel by arc-assisted laser welding, J. Manuf. Process, 25 (2017), 123-133. http://dx.doi.org/10.1016/j.jmapro.2016.11.014

35. L. Cui, B. Chen, L. Chen, D. He, Dual beam laser keyhole welding of steel/aluminum lapped joints, J. Mater. Process. Tech, 256 (2018), 87-97

36. H.J. Park, S., Rhee, M.J. Kang and D.C. Kim, Joining of steel to aluminum alloy by AC pulse MIG welding, Mater. Trans, 50(9) (209), 2314-2317 http://dx.doi.org/10.2320/matertrans.M2009105

37. Y. Shi, L. Shao, J. Huang and Y. Gu, Effects of Si and $\mathrm{Mg}$ elements on the microstructure of aluminum - steel joints produced by pulsed DE-GMA welding / brazing, Mater. Sci. Tech, 29(9) (2013), 1188-1124 https://doi.org/10.1179/1743284713Y.0000000291

38. Y. Shi, G. Zhang, Y. Huang, L. Lu, J. Hunag and Y. Shao, Pulsed double-electrode GMAW-brazing for joining of aluminum to steel, Weld. J, 93(6) (2014), 216s-224s

39. L. Shao, Y. Shi, J.K. Huang and S.J. Wu, Effect of joining parameters on microstructure of dissimilar metal joints between aluminum and galvanized steel, Mater. Design, 66(B) (2015), 453-458 https://doi.org/10.1016/j.matdes.2014.06.026

40. K.P. Yagati, R.N. Bathe, K.V. Raajulapati, K.B.S. Rao and G. Padmanabham, Fluxless arc weld-brazing of aluminium alloy to steel, J. Mater. Process. Tech, 214(12) (2014), 2949-2959 https://doi.org/10.1016/j.jmatprote c.2014.06.017

41. H.T. Zhang, J.C Feng, P. He, B.B. Zhang, J.M. Chen and L. Wang, The arc characteristics and metal transfer behaviour of cold metal transfer and its use in joining aluminium to zinc-coated steel, Mater. Sci. Eng. A, 499 (1-2) (2009), 111-113 https://doi.org/10.1016/j.msea.2007.11.124

42. H.T. Zhang, J.C. Feng, P. He and H. Hackl, Interfacial 
microstructure and mechanical properties of aluminium-zinc-coated steel joints made by a modified metal inert gas welding-brazing process, Mater. Charact, 58 (2007) 588-592 https://doi.org/10.1016/j.matchar.2006.07.008

43. H.T. Zhang, J.C. Feng and P. He, Interfacial phenomena of cold metal transfer (CMT) welding of zinc coated steel and wrought aluminium, Mater. Sci. Tech, 24(11) (2008) 1346-1349 https://doi.org/10.1179/174328407X213152

44. M. Kang and C. Kim, Joining Al 5052 alloy to aluminized steel sheet using cold metal transfer process, Mater. Design, 81 (2015), 95-103 https://doi.org/10.1016/j.matdes.2015.05.035

45. A. Das, M. Shome, C.R. Das, S.F. Goecke and A. De, Joining of galvannealed steel and aluminium alloy using controlled short circuiting gas metal arc welding process, Sci. Technol. Weld. Joi, 20(5) (2015), 402-408 https://doi.org/10.1179/1362171815Y.0000000032

46. A. Das, M, Shome, S.F. Goecke and A. De, Numerical modelling of gas metal arc joining of aluminium alloy and galvanized steels in lap joint configuration, Sci. Technol. Weld. Joi, 21(4) (2016), 303-309 https://doi.org/10.1080/13621718.2015.1104206

47. A.M. Milani, M. Paider, A. Khodabandeh and S. Nategh, Influence of filler wire and wire feed speed on metallurgical and mechanical properties of MIG welding brazing of automotive galvanized steel/5754 aluminum alloy in a lap joint configuration, Int. J. Adv. Manuf. Tech, 82(9-12) (2016), 1495-1506 https://doi.org/10.1007/s00170-015-7505-4

48. Q. Chang, D. Sun, X. Gu, H. Li, Microstructures and mechanical properties of metal inert-gas arc welded joints of aluminum alloy and ultrahigh strength steel using $\mathrm{Al}-\mathrm{Mg}$ and $\mathrm{Al}-\mathrm{Cu}$ fillers, J. Mater. Res, 32(3) (2017), $1-11$ https://doi.org/10.1557/jmr.2016.487

49. H. Ma, G. Qin, X. Bai, L. Wang, Z. Liang, Effect of initial temperature on joint of aluminum alloy to galvanized steel welded by MIG arc brazing-fusion welding process, Int. J. Adv. Manuf. Tech, 86(9-12) (2016), 31353143 https://doi.org/10.1007/s00170-016-8425-7

50. S. Madhavan, M. Kamaraj, L. Vijayaraghavan, K.S. Rao, Microstructure and mechanical properties of aluminium/steel dissimilar weldments: effect of heat input, Mater. Sci. Tech, 33(2) (2017), 200-209 https://doi.org/10.1080/02670836.2016.1176716

51. Z. Ye, J. Huang, W. Gao, Y. Zhang, Z. Cheng, S. Chen, J. Yang, Microstructure and mechanical properties of 5052 aluminum alloy/mild steel butt joint achieved by MIG-TIG double-sided arc welding-brazing, Mater. Design, 123 (2017), 69-79 https://doi.org/10.1016/j.matdes.2017.03.039

52. Z. Ye, J. Huang, Z. Cheng, L. Xie, Y. Zhang, S. Chen, J. Yang, Study on butt joining 5052 aluminum alloy/ Q235 mild steel by MIG-TIG double-sided arc welding-brazing process, Weld. World, 62(1) (2018), 145-154 https://doi.org/10.1007/s40194-017-0516-z 